\title{
THE GENUS COLURA SECTION GLOTTA (LEJEUNEACEAE, MARCHANTIOPHYTA) IN THAILAND
}

\author{
J. SANGrattanaprasert ${ }^{1}$, S. Chantanaorrapint ${ }^{1}$ and R.-L. ZhU ${ }^{2}$ \\ ${ }^{1}$ Department of Biology, Faculty of Science, Prince of Songkla University \\ Hat Yai, Songkhla 90112, Thailand; E-mail: chantanaorrapint@gmail.com \\ ${ }^{2}$ Department of Biology, School of Life Sciences, East China Normal University \\ 3663 Zhong Shan Road, Shanghai 200062, China; E-mail: rlzhu@bio.ecnu.edu.cn
}

(Received 18 December, 2017; accepted 15 March, 2018)

The genus Colura (Dumort.) Dumort. sect. Glotta Grolle et R. L. Zhu in Thailand is studied based on herbarium specimens and especially on recent collections. The section is reported from Thailand for the first time. Two species are recognized, namely C. bisvoluta Herzog et Jovet-Ast and C. karstenii K. I. Goebel. Descriptions, illustrations, and a key to species are provided.

Key words: bryoflora, Colura sect. Glotta, leafy liverwort, Malesian region, Thailand

\section{INTRODUCTION}

The genus Colura (Dumort.) Dumort. is one of the large genera of the Lejeuneaceae and divided into two subgenera and six sections with about 83 currently accepted species (Grolle and Zhu 2002, Söderström et al. 2016). The section Glotta Grolle et R. L. Zhu was first known as sect. Lingua Jovet-Ast subsect. 2 (Jovet-Ast 1953), which was invalid due to the lack of Latin diagnosis and type of the subsection. Later, this section was re-established by Grolle and Zhu (2002) based on C. bisvoluta Herzog et Jovet-Ast. The section Glotta is easily separated from other sections of Colura by the lateral leaves being monomorphic with saccate lobule, the presence of a large lingulate valve composed of 60-300 cells, and the lack of a hinge. The section contains eight species, and is distributed widely from tropical Africa, tropical and subtropical Asia, to the Pacific Islands (Grolle and Zhu 2002).

Although the comprehensive taxonomic revision of Colura was published by Jovet-Ast (1953), the genus is still rather poorly studied in Thailand. The first report of Colura in Thailand was published by Reede and Robinson (1967), who reported C. acroloba (Mont. ex Steph.) Jovet-Ast from Khao Yai National Park. Later, several authors recorded additional species from vari- 
ous localities, e.g., Jovet-Ast (1968), Tixier (1970, 1973), Lai et al. 2008, Chantanaorrapint and Pócs (2014), Pócs and Podani (2015), and Sangrattanaprasert et al. (2017). So far, 13 species in two sections (Harmophyllum Grolle and Heterophyllum Jovet-Ast) were reported for the country. The section Glotta had not been reported from Thailand, probably due to the rareness of bryological surveys in this country. During bryological expeditions in Thailand between 2014 and 2016, the genus Colura section Glotta was found in northeastern, central, and peninsular Thai floristical regions.

\section{MATERIAL AND METHODS}

The present work is based on recent collections from Thailand as well as herbarium specimens housed in BCU, EGR, HSNU, JE, MO, and PSU. Morphological and anatomical characters are observed by stereo and upright microscopes. All significant characters are illustrated with the aid of an Olympus drawing tube.

\section{TAXONOMIC TREATMENTS}

There are two species of Colura sect. Glotta occurring in Thailand: C. bisvoluta and C. karstenii. Keys for distinguishing these two species are as below: Lobule sacs obovate to slightly elliptical, surface strongly mamillose, valves consisting of 70-170 cells. Perianth obovate with 3 keels C. bisvoluta

Lobule sacs ovate to slightly elliptical, surface nearly smooth to slightly mamillose, valves consisting of more than 300 cells. Perianth obdeltoid to oblong with 5 keels

C. karstenii

Colura bisvoluta Herzog et Jovet-Ast, Rev. Bryol. Lichénol. 22: 228 (1953) (Figs 1, 2)

Type: Indonesia, West Sumatra, “Lobang-Karbau” prope Fort de Kock, coll.: V. Schiffner 3480 (holotype: JE; isotype: JE!).

Plants pale green, $\mathrm{ca} 4 \mathrm{~mm}$ long; shoots $1.5-2 \mathrm{~mm}$ wide; irregularly pinnately branched, branches of Lejeunea-type. Stem $65-110 \mu \mathrm{m}$ in diameter, in transverse section consisting of 7 cortical cells $(20-40 \times 20-25 \mu \mathrm{m})$ and 3 medullary cells (15-30 × 10-25 $\mu \mathrm{m})$; ventral merophytes of stem 2 cells wide. Rhizoids numerous, fasciculate at base of underleaves. Leaves imbricate to contiguous, spreading from stem $40-50^{\circ}$ angle. Lobes $0.7-0.86 \mathrm{~mm}$ long, $0.32-$ $0.5 \mathrm{~mm}$ wide; dorsal margin revolute, $2-3$ cells wide. Lobe cells thin-walled, 

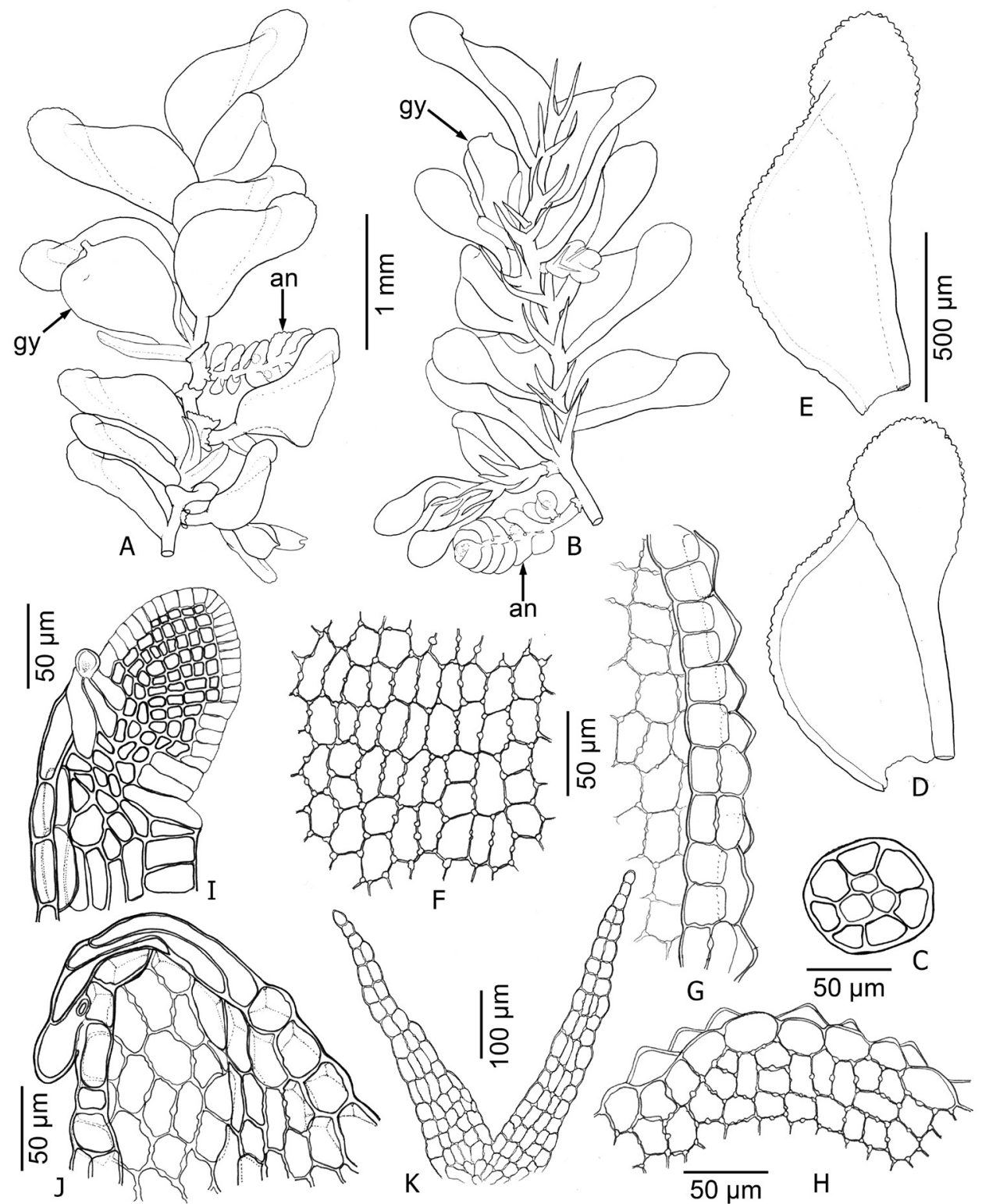

Fig. 1. Colura bisvoluta Herzog et Jovet-Ast. A-B = Portion of plant with androecia (an) and gynoecia (gy), $\mathrm{A}=$ dorsal view, $\mathrm{B}=$ ventral view; $\mathrm{C}=$ Stem in transverse section; $\mathrm{D}-\mathrm{E}$ = Lateral leaf, $\mathrm{D}=$ ventral view, $\mathrm{E}=$ dorsal view; $\mathrm{F}-\mathrm{G}=$ Leaf lobe cell, $\mathrm{F}=$ median cell, $\mathrm{G}=$ marginal cell; $\mathrm{H}$ = Lobule sac apex; $\mathrm{I}=$ Valve; $\mathrm{J}=$ Valve frame; $\mathrm{K}=$ Underleaf. All from Sangrattanaprasert 423/15B (PSU) 
trigones medium sized, intermediate thickenings distinct; marginal cells isodiametric to subquadrate, 20-30 × 10-20 $\mu \mathrm{m}$; median cells rectangular, 20-42 $\times 18-20 \mu \mathrm{m}$; basal cells rectangular, $26-50 \times 16-36 \mu \mathrm{m}$. Cuticle smooth. Oil
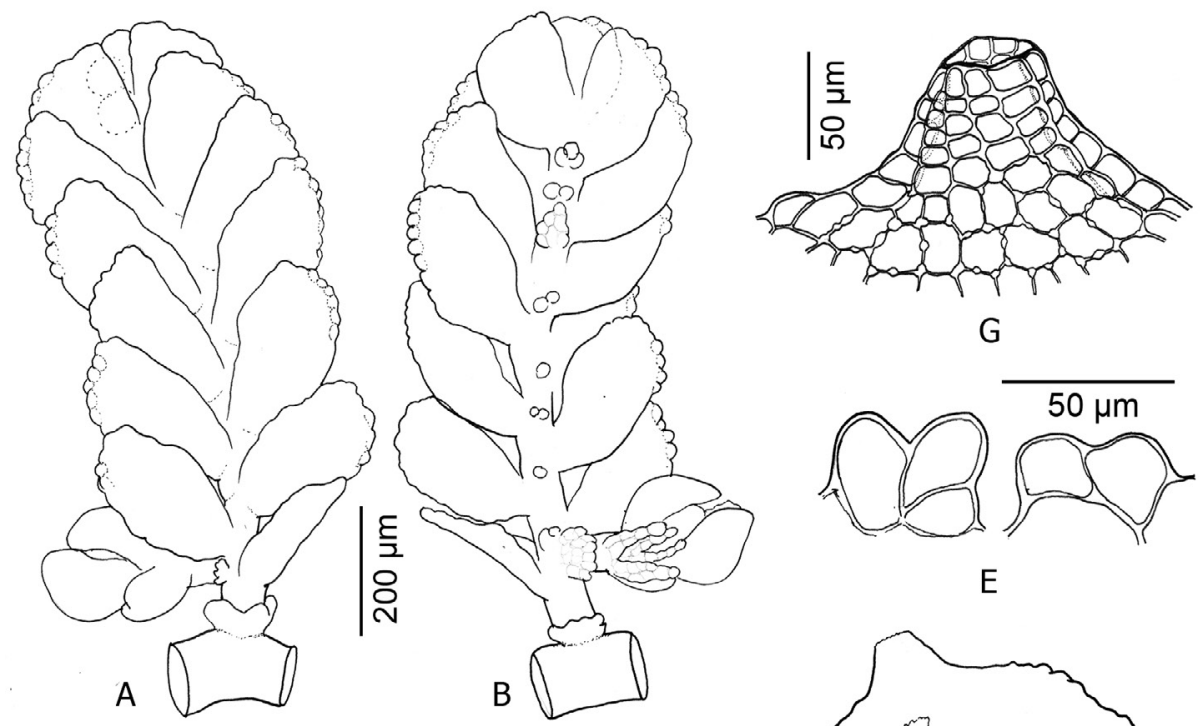

$\mathrm{E}$

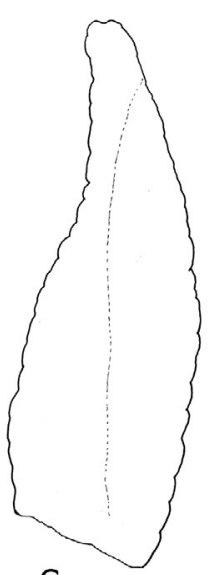

C
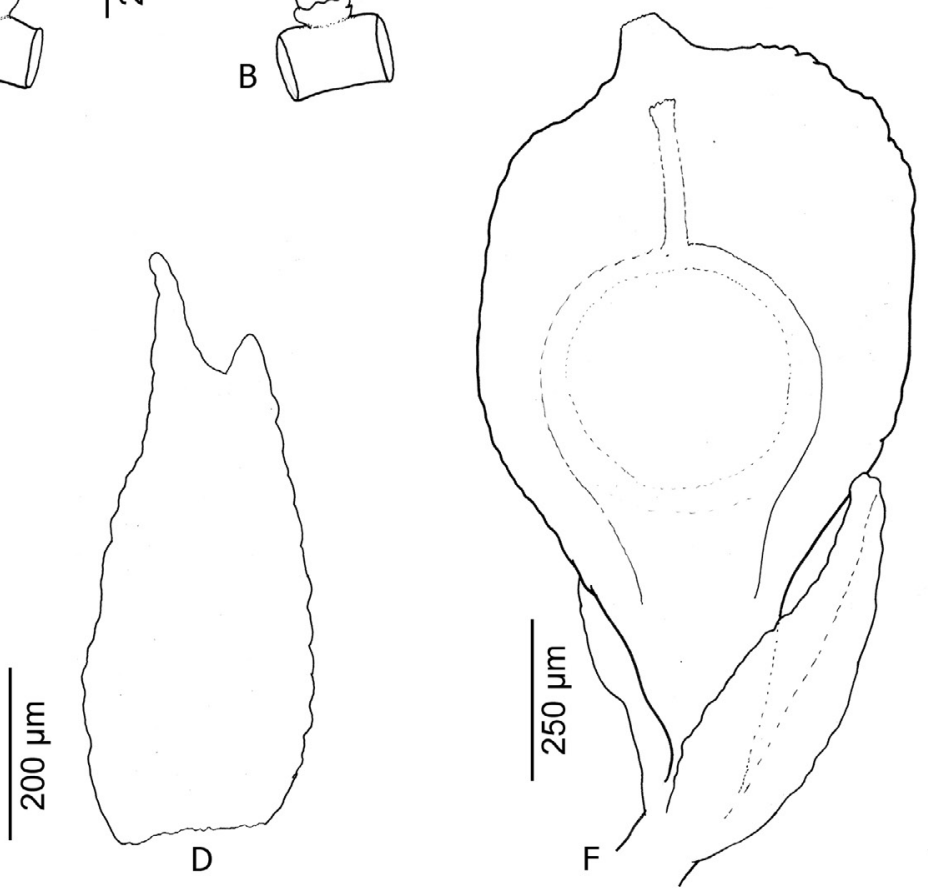

Fig. 2. Colura bisvoluta Herzog et Jovet-Ast. $\mathrm{A}-\mathrm{B}=$ Androecia, $\mathrm{A}=$ dorsal view, $\mathrm{B}=$ ventral view; $\mathrm{C}-\mathrm{D}=$ Female bract, $\mathrm{C}=$ dorsal view, $\mathrm{D}=$ ventral view; $\mathrm{E}=$ Female bracteoles; $\mathrm{F}=$ Perianth with young sporophyte; $G=$ Perianth beak. All from Sangrattanaprasert 423/15B (PSU) 
bodies 7-12 per cell, roughly segmented, ellipsoid, 4-6 $\times 2 \mu \mathrm{m}$. Lobules narrowly tubular, flaring toward sac, $0.9-1.2 \mathrm{~mm}$ long. Lobule sac obovate to slightly elliptical, strongly inflated, $0.44-0.6 \mathrm{~mm}$ long, $0.3-0.4 \mathrm{~mm}$ wide, sac surface mamillose, apex obtuse, entire. Valves simple-type, lingulate, 140-160 $\times 90-100 \mu \mathrm{m}$, composed of one circle of 25-40 hyaline marginal and 40-130 median cells without basal median cell and hinge. Hyaline papilla bulbous, $12-16 \mu \mathrm{m}$ in diameter. Valve frame outline semicircular with cell triseriate, 100-140 $\mu \mathrm{m}$ wide; cell wall smooth. Underleaves distant, deeply bilobed, sinus obtuse; lobe lanceolate, $320-440 \times 56-80 \mu \mathrm{m}, 12-17$ cells long, $4-5$ cells wide at base; margin entire.

Autoicous. Androecia terminal on lateral branch; male bract hemispherical, apical keel crenulate with one projecting cell row, free margin entire, in ca 5 pairs; bract lobes semicircular, 160-206 $\times 96-144 \mu \mathrm{m}$; bract lobules semicircular, $152-176 \times 120-128 \mu \mathrm{m}$, bract lobules almost as large as bract lobes; antheridia 2 per bract; male bracteoles entire to bilobed, few- to severalcelled. Gynoecia terminal on lateral branch with 1 pycnolejeunoid innovation branch; female bracts ovate to slightly lanceolate, $640-680 \times 150-176 \mu \mathrm{m}$; bract lobules narrowly oblong, ca $640 \times 88-136 \mu \mathrm{m}$; female bracteole very small, composed of 2-3 cells. Perianth obovate, $0.8-1.0 \mathrm{~mm}$ long, $0.4-0.64 \mathrm{~mm}$ wide, with 3 keels; keels flat, ridge-shaped, entire; beak 5 cells long. Sporophyte and asexual reproduction not seen.

Representative specimens examined: THAILAND. Chumphon Province: Heo Lom Waterfall, 09 43' 47.89" N, 98 40' 58.50" E, 105 m, coll.: Chantanaorrapint and Promma 3899B, 4 August 2014, (PSU); Phangnga Province: Si Phang-nga National Park, Ton Deng Waterfall, 08 59' 30.96" N, 98 27' 56.77" E, $70 \mathrm{~m}$, coll.: Chantanaorrapint and Promma 3890B, 3 August 2014, (PSU); coll.: Sangrattanaprasert 423/15B, 9 October 2015 (PSU).

Habitat and ecology: In Thailand, Colura bisvoluta is rare and seemingly found only in Chumphon and Phangnga Province. This species grows on palm leaves in lowland rainforests near the waterfall associated with other epiphyllous liverworts such as C. acroloba (Mont. ex Steph.) Jovet-Ast, Caudalejeunea reniloba Steph., Cololejeunea spp., and Leptolejeunea sp.

Distribution: Australia (Queensland), Indonesia (West Sumatra), Malaysia (Malacca) (Jovet-Ast 1953). New to Thailand.

Taxonomic notes: Colura bisvoluta is morphologically similar to C. queenslandica B. M. Thiers, an endemic species to Australia. The latter, however, differs from the former by the transverse section of stem consisting of 6 cortical cells and 1 medullary cell, the dorsal margin of leaf lobe being flattened, the lobe and lobule surface without conically protuberant mamillae, the smaller valve with $47-50$ cells, and the perianth having 5 keels. 
Colura karstenii K. I. Goebel, Pflanzenbiol. Schilder. 2: 153 (1891) (Figs 3, 4)

Type: Indonesia, Amboyna island, Wawani Hali, coll.: G. Karsten s.n. (holotype: G).

Plants dull green, 1-1.5 cm long; shoots 2-5 mm wide; irregularly pinnately branched, branches of Lejeunea-type. Stem 150-250 $\mu \mathrm{m}$ in diameter, in transverse section consisting of 7 cortical cells $(45-75 \times 34-70 \mu \mathrm{m})$ and 3 medullary cells $(30-68 \times 26-64 \mu \mathrm{m})$; ventral merophytes of stem 2 cells wide. Rhizoids numerous, fasciculate at base of underleaves. Leaves imbricate, spreading from stem 30-60 angle. Lobes 2.1-3.4 mm long, 0.7-1 mm wide; dorsal margin strongly revolute, 4-5 cells wide. Lobe cells thin-walled, trigones large, intermediate thickening very distinct; marginal cells isodiametric to subquadrate, 26-40 × 20-28 $\mu \mathrm{m}$; median cells rectangular to slightly hexagonal, 30-70 × 18-30 $\mu \mathrm{m}$; basal cells rectangular, 44-70 × 24-34 $\mu \mathrm{m}$. Cuticle smooth. Oil bodies 8-18 per cell, roughly segmented, ellipsoid, 5.5-9.6 × 3-4 $\mu \mathrm{m}$. Lobules narrowly tubular, flaring toward sac, $2.6-4.1 \mathrm{~mm}$ long. Lobule sac ovate to slightly elliptical, strongly inflated, $1.2-1.4 \mathrm{~mm}$ long, $0.8-0.85 \mathrm{~mm}$ wide, sac surface nearly smooth to slightly mamillose, apex obtuse, entire. Valves simple-type, lingulate, 440-480 × 320-336 $\mu \mathrm{m}$, composed of one circle of 40-70 hyaline marginal and 130-275 median cells without distinction of basal median cell and hinge. Hyaline papilla bulbous, 20-24 $\mu \mathrm{m}$ in diameter. Valve frame outline semicircular with cell triseriate, 260-520 $\mu \mathrm{m}$ wide; cell wall undulated. Underleaves distant, deeply bilobed, sinus obtuse; lobe lanceolate to acuminate, 360-640 × 64-150 $\mu \mathrm{m}, 12-19$ cells long, 4-9 cells wide at base; margin entire.

Dioicous. Androecia lateral on main stem; male bracts hemispherical, apical keel entire, free margin entire, in 5-9 pairs; bract lobes, semicircular, 220-280 × 140-220 $\mu \mathrm{m}$; bract lobules as large as bract lobes, semicircular, 200 $280 \times 120-160 \mu \mathrm{m}$; antheridia 2 per bract; male bracteoles bilobed, slightly small. Gynoecia terminal on lateral branch with 1 pycnolejeunoid innovation branch; female bracts oblong to slightly elliptical, 900-1,120 × 260-360 $\mu \mathrm{m}$; bract lobules narrowly oblong, 840-900 × 95-180 $\mu \mathrm{m}$; female bracteole bilobed to linear, small with a few cells. Perianth obdeltoid to oblong, 1.9-2 mm long, 0.6-0.7 mm wide, with 5 keels; keels short, entire; beak 3-5 cells long. Sporophyte. Seta articulate, $c a 14$ cells long; in transverse section with 4 inner and 12 outer cells. Capsule slightly spherical, $c a 260 \mu \mathrm{m}$ in diameter, splitting $\pm 4 / 5$ its length into four erect valves after dehiscence; capsule valve 430-480 × 250-280 $\mu \mathrm{m}$, wall 2-3 stratose, hyaline. Outer layer capsule valve apex formed by one quadrate cell; cell of upper part ca $4 / 5$ of valve, slightly rhombic, large, thickwalled, nodulose; hinge ca 1/5 of valve length, butterfly-shaped, hinge cell 

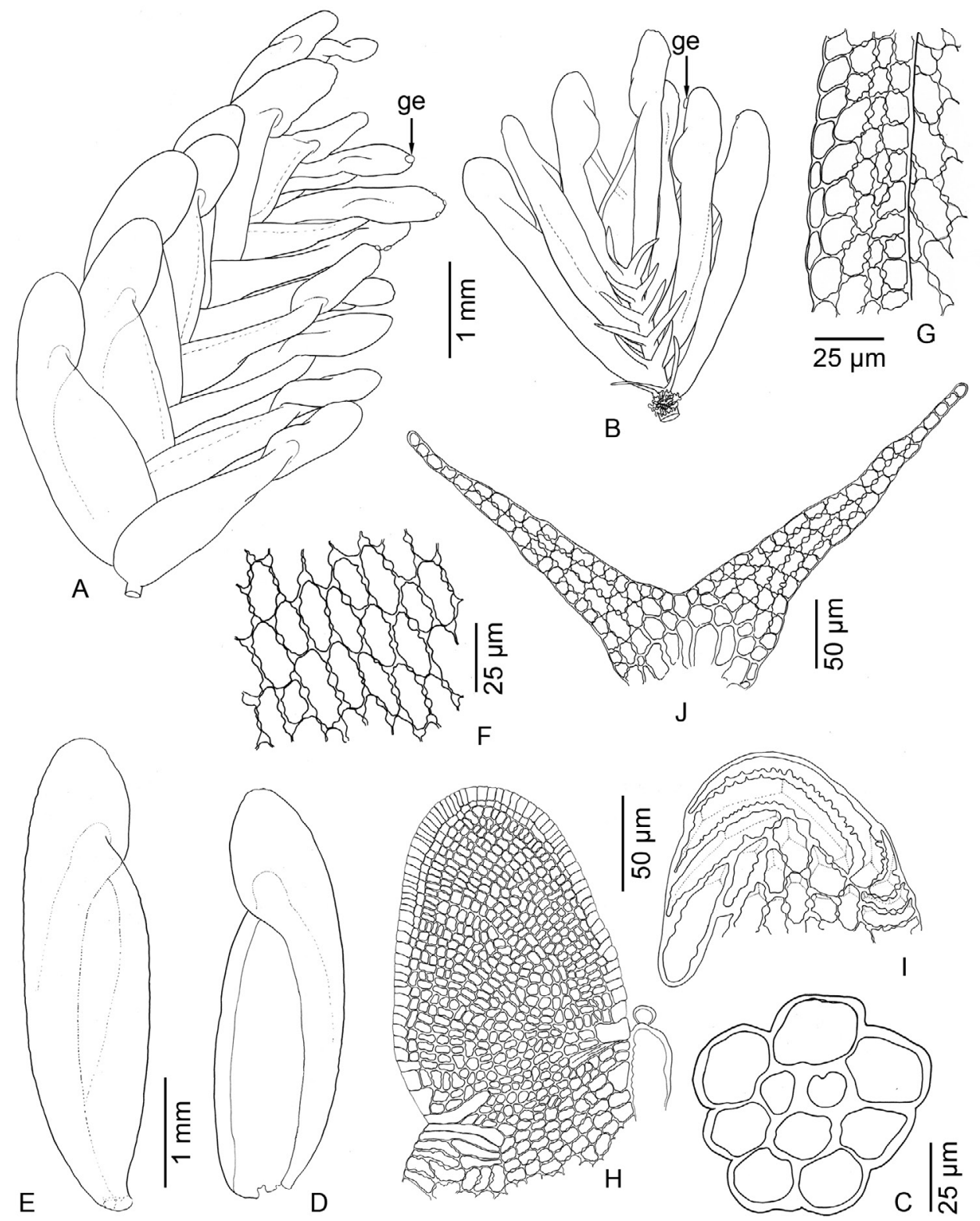

Fig. 3. Colura karstenii K. I. Goebel. A-B = Portion of plant with gemmae (ge) on lobule sac, $\mathrm{A}=$ dorsal view; $\mathrm{B}=$ ventral view; $\mathrm{C}=$ Stem in transverse section; $\mathrm{D}-\mathrm{E}=$ Lateral leaf, $\mathrm{D}=$ ventral view, $\mathrm{E}=$ dorsal view; $\mathrm{F}-\mathrm{G}=$ Leaf lobe cell; $\mathrm{F}=$ median cell; $\mathrm{G}=$ marginal cell; $\mathrm{H}=$ Valve; I = Valve frame; J = Underleaf. All from Sangrattanaprasert 116/14A (PSU) 

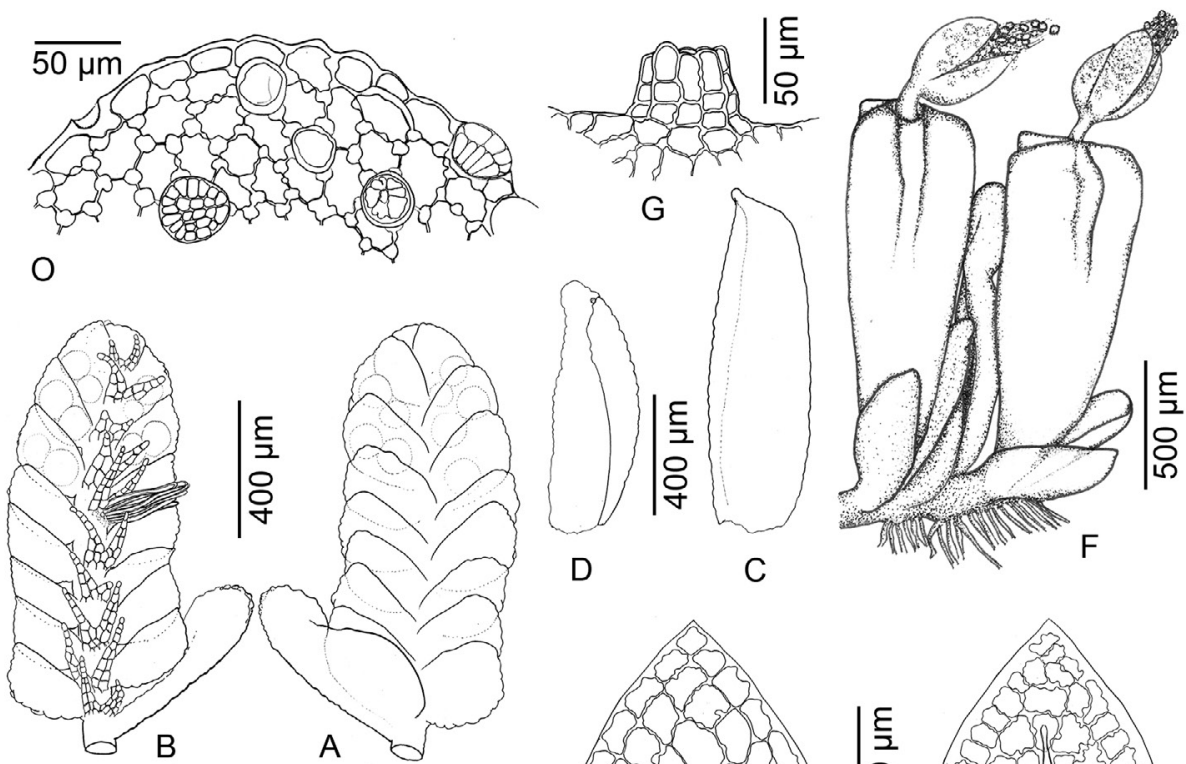

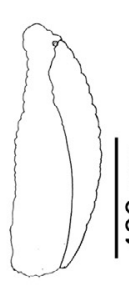

$\mathrm{D}$
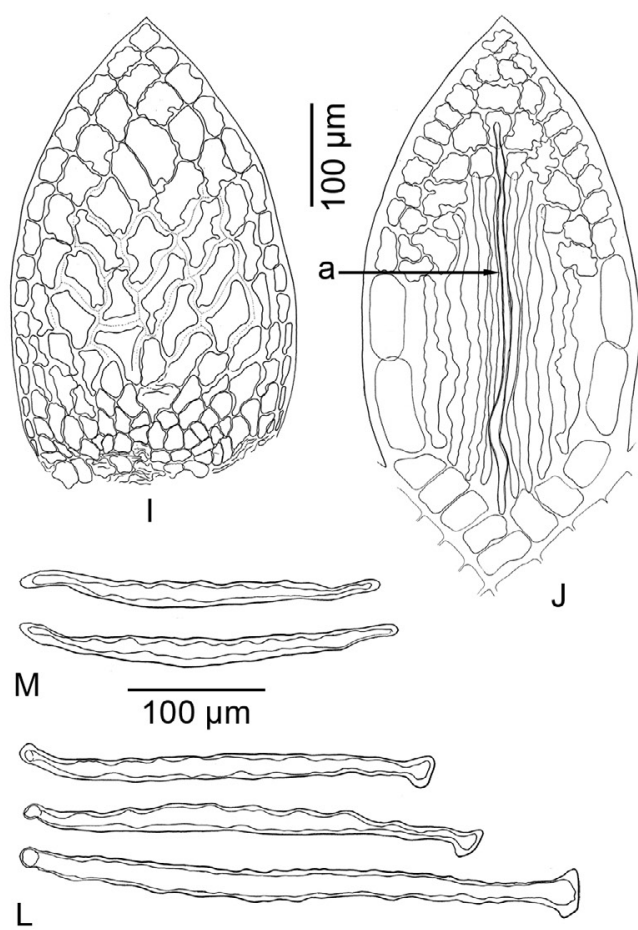

Fig. 4. Colura karstenii K. I. Goebel. A-B = Androecia, A = dorsal view, B = ventral view; C-D $=$ Female bract, $\mathrm{C}=$ dorsal view, $\mathrm{D}=$ ventral view; $\mathrm{E}=$ Female bracteole; $\mathrm{F}=$ Perianths with sporophytes; $\mathrm{G}=$ Perianth beak; $\mathrm{H}=$ Mature sporophyte; $\mathrm{I}=$ Outer layer valve; $\mathrm{J}=$ Inner layer valve $(\mathrm{a}=$ additional elater $) ; \mathrm{K}=$ Scheme of elaters distribution $(\mathrm{lm}=$ lower marginal elater, $\mathrm{um}=$ upper marginal elater); $\mathrm{L}=$ Upper marginal elaters; $\mathrm{M}=$ Lower marginal elaters; $\mathrm{N}=$ Sporeling; $\mathrm{O}=$ Gemmae occurring on lobule sac surface. A-B from Sukkharak and Seelanan 437 (BCU), C-O from Sangrattanaprasert 116/14A (PSU) 
subquadrate, smaller than upper half cells, thin-walled; marginal cells rectangular, formed by 1 row. Inner layer capsule valve cells in centre rectangular, walls with nodular thickenings; marginal cells of upper half subquadrate, walls nodulose, formed by 2 rows, marginal cells of lower half rectangular, wall smooth; basal cell subquadrate, walls smooth. Elaters of two types: marginal and additional; marginal elaters 22 per capsule, each valve contains 4 or 5 upper marginal elaters and 2 or no lower marginal elaters; upper marginal elaters attached to upper half of valve margin by one end, 270-400 $\mu \mathrm{m}$ long, 20-32 $\mu \mathrm{m}$ wide, hyaline, with irregular thickening, end attached to valve margin rounded, not expanded, free end dilated; lower marginal elaters attached to valve at both ends (near and parallel to basal margin), 260-280 $\mu \mathrm{m}$ long, 20-22 $\mu \mathrm{m}$ wide, hyaline, with irregular to annular thickening, upper end narrowly tapered, lower end obtuse; additional elaters 4 per capsule ( 1 per each valve), 340-380 $\mu \mathrm{m}$ long, 6-10 $\mu \mathrm{m}$ wide, hyaline, with irregular thickening or smooth, attached along their whole length to median part of valve, even upon dehiscence. Spores green, irregular-oblong or elongate-rectangular, 66-90 × 34-48 $\mu \mathrm{m}$; spore surface covered with irregular lamellae; sporeling Lejeuneatype. Asexual reproduction by discoid gemmae, occurring on lobule sac.

Representative specimens examined: MALAYSIA. Kedah State: Gunung Jerai Mountain, $05^{\circ} 47.8^{\prime} \mathrm{N}, 100^{\circ} 26.1^{\prime} \mathrm{E}, 900-1,150 \mathrm{~m}$, coll.: S. and T. Pócs 1008/J, 1009/G, 21 February 2010, (EGR); Sabah State: Sandakan city, Sepagara Forest Reserve, along Kalung-Kalungan trail, 04 57' 54.76" N, 118 10' 22.39" E, 490 m, coll.: Zhu, Shu and Yin 20160915-21A, 15 September 2016 (HSNU). THAILAND. Loei Province: Phu Luang Widlife Sanctuary, trail from Talearn to Dinosaur footprints, $17^{\circ} 17^{\prime} 51.76^{\prime \prime} \mathrm{N}, 101^{\circ} 31^{\prime} 39^{\prime \prime} \mathrm{E}, 1,280-1,460 \mathrm{~m}$, coll.: Si He 46858A, 19 February 2016 (MO, PSU); Nakhon Nayok Province: Khao

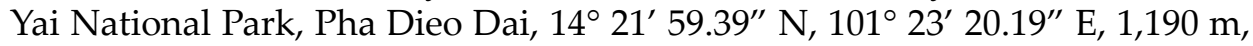
coll.: Sangrattanaprasert 30/13A, 39/13A, 14 November 2013 (PSU); coll.: Sangrattanaprasert 341/15, 1 June 2015 (PSU); Nakhon Si Thammarat Province: Khao Nan National Park, 1,100 m, coll.: Sukkhalak and Seelanan 437, 369B, 10-11 August 2007 (BCU); coll.: Chantanaorrapint 08-031, 28 February 2008 (EGR); Trang Province: Khao Chedyod, 1,040-1,070 m, coll.: Sangrattanaprasert 115/14B, 116/14A, 134/14A, 144/14, 2 May 2014 (PSU).

Habitat and ecology: In Thailand, Colura karstenii often occurs on twigs in montane forest at altitude between 1,000 and 1,450 m.

Distribution: China (Hainan), Indonesia (Amboyna Island), Malaysia (Malay Peninsula), Vietnam (Jovet-Ast 1953, Tixier 1962, Zhu and So 2001). New to Thailand.

Taxonomic notes: This species is morphologically similar to C. strophiola$t a$ Jovet-Ast, which was found in Cambodia and Malaysia, but the latter was distinguished by the longer lateral leaves $c a 4.5 \mathrm{~mm}$ in length and the wider 
underleaves with 10 cells width at base (Jovet-Ast 1976). Colura karstenii, however, shows the variations in leaf and underleaf sizes, which may likely overlap C. strophiolata. Thus, these two species may possibly be conspecific, and the molecular phylogenetic study is needed to determine the interrelationships among them.

Acknowledgements - The authors would like to thank the curators and other staffs of BCU, EGR, HSNU, JE, MO, and PSU for making specimens, including types available for study through loans and visits; and Prof. Dr Tamás Pócs (EGR) and the anonymous reviewer for their helpful remarks and suggestions on the manuscript. This research was financially supported by Graduated School, Prince of Songkla University and by the National Natural Science Foundation of China (nos. 31570206, 31770224). Finally, funding by the Science Achievement Scholarship of Thailand (SAST) is gratefully acknowledged by the first author.

\section{REFERENCES}

Chantanaorrapint, S. and Pócs, T. (2014): Southern Thailand bryophytes I, with description of Cololejeunea ramromensis. - In: Telnov, D. (ed.): Biodiversity, biogeography and nature conservation in Wallacea and New Guinea, II. The Entomological Society of Latvia, Rìga, pp. 113-122.

Grolle, R. and Zhu, R.-L. (2002): On Macrocolura and the subdivision of Colura (Lejeuneaceae, Hepaticae). - J. Hattori Bot. Lab. 92: 181-190.

Jovet-Ast, S. (1953): Le genre Colura, Hépatiques, Lejeuneacées, Diplasiae. - Rev. Bryol. Lichénol. 22: 206-312.

Jovet-Ast, S. (1968): Colura récoltés du Pakistan aux Philippens par Pierre Tixier. - Rev. Bryol. Lichénol. 35: 138-142.

Jovet-Ast, S. (1976): Compléménts a la connaissance des Colura: espece et localités Nouvelles. - Rev. Bryol. Lichénol. 42: 909-922.

Lai, M.-J., Zhu, R.-L. and Chantanaorrapint, S. (2008): Liverworts and hornworts of Thailand: and updated checklist and bryofloristic accounts. - Ann. Bot. Fennici 45: 321341. https://doi.org/10.5735/085.045.0501

Pócs, T. and Podani, J. (2015): Southern Thailand bryophytes II. Epiphylls from the PhangNga area. - Acta Bot. Hung. 57: 183-198. https://doi.org/10.1556/ABot.57.2015.1-2.14

Reede, C. F. and Robinson, H. (1967): Contribution to the bryophytes of Thailand I. - Phytologia 15: 61-70.

Sangrattanaprasert, J., Chantanaorrapint, S. and Zhu, R.-L. (2017): Notes on Colura crenulata (Lejeuneaceae, Marchantiophyta), a new record for Thailand, with a sporophyte description. - Polish Bot. J. 62(2): 197-202. https://doi.org/10.1515/pbj-2017-0014

Söderström, L., Hagborg, A., Von Konrat, M., Bartholomew-Began, S., Bell, D., Briscoe, L., Brown, E., Cargill, D. C., Costa, D. P., Crandall-Stotler, B. J., Cooper, E. D., Dauphin, G., Engel, J. J., Feldberg, K., Glenny, D., Gradstein, S. R., He, X., Heinrichs, J., Hentschel, J., Ilkiu-Borges, A. L., Katagiri, T., Konstantinova, N. A., Larraín, J., Long, D. G., Nebel, M., Pócs, T., Puche, F., Reiner-Drehwald, E., Renner, M. A. M., Sass-Gyarmati, A., Schäfer-Verwimp, A., Segarra Moragues, J. G., Stotler, R. E., Suk- 
kharak, P., Thiers, B. M., Uribe, J., Váňa, J., Villarreal, J. C., Wigginton, M., Zhang, L. and Zhu, R.-L. (2016): World checklist of hornworts and liverworts. - PhytoKeys 59: 1-828. https://doi.org/10.3897/phytokeys.59.6261

Tixier, P. (1962): Bryophytes du Vietnam. Premières récoltes dans le massif de Bach-Ma. Rev. Bryol. Lichénol. 31: 190-203.

Tixier, P. (1970): Bryophyte Indosinicae. Bryophytes from Thai Tenasserim. - Nat. Hist. Bull. Siam. Soc. 23: 541-559.

Tixier, P. (1973): Bryophyte Indosinicae. Liverworts collected in Thailand. - Nat. Hist. Bull. Siam. Soc. 23: 449-456.

Zhu, R.-L. and So, M. L. (2001): Epiphyllous liverworts of China. - Nova Hedwigia, Beih. 121: $1-418$. 